\title{
Cidade de Belém e natureza: uma relação problemática?
}

Violeta Reflealefsky Loureiro - Professora da Universidade Federal do Pará (PPGCS e PPGD). Doutora em Sociologia do Desenvolvimento pela Universidade de Paris III - França, Pósdoutorado no Centro de Estudos Sociais, da Univ. de Coimbra-Portugal. E-mail: violeta. loureiro@ig.com.br. E-mail: violeta.loureiro@ig.com.br

Estêvão José da Silva Barbosa - Geógrafo, Mestre em Geografia, Especialista em geografia urbana, ex-diretor do NURI/SEDECT-PA. E-mail: estevaobarbosa@yahoo.com.br

\section{Resumo}

Belém vem perdendo, de forma incessante e rápida, o seu verde urbano. Essa perda apresenta características singulares, quando comparada a que outras cidades brasileiras igualmente sofrem face ao processo de especulação urbana e à ocupação desordenada do solo. Na cidade das mangueiras, são justamente elas, as mangueiras - tombadas pelo Patrimônio como bem de uso comum e preservação permanente - as espécies que padecem maiores danos, descaracterizando a cidade como tal. Além disso, diferentemente de outras capitais, onde a iniciativa privada tem sido responsável pela maior parte dos danos ambientais, em Belém, as ações e omissões do poder público em relação à cidade, respondem mais gravemente que o setor privado, pela deterioração da paisagem urbana, seja no que concerne ao verde, seja no que diz respeito às águas internas da cidade.

\section{Palavras-chave}

Arborização urbana. Mangueiras. Belém. Verde urbano.

\begin{abstract}
In an unstoppable and rapid manner, Belém is losing it's urban green. This loss presents itself with unique characteristics when compared to other Brazilian cities, that equally suffer from the urban speculation and the chaotic occupancy of the land. The mango trees - witch are listed as part of the State's patrimony as common goods and must be permanently preserved - are actually the most endangered species, no longer characterizing Belém as the mango tree's city. Besides, differently from the other capitals, where the private sector has been the most res ponsible for the environment damage, in Belém, actions and omissions of the government to the city are more important to the deterioration of the urban landscape, it's green areas and waters than the private sector.
\end{abstract}

\section{Keywords}

Urban trees. Mango tree. Belém. Urban green. 


\section{INTRODUÇÃO: A IMPORTÂNCIA DO VERDE VIÁRIO NAS CIDADES}

O verde urbano é constituído pela vegetação existente nas cidades e seus arredores imediatos - subúrbios, áreas de expansão urbana. Em razão do contexto em que se localiza e, principalmente, da funcionalidade que exerce para a vida urbana, ele é classificado como: vegetação do interior de terrenos privados ou públicos, que são de uso restrito; vegetação das unidades e áreas legais de conservação ou preservação; área verde, quando compõe a paisagem dos locais “abertos" destinados ao lazer, recreação e contemplação, como são os parques e as praças; e verde viário, que engloba a vegetação situada ao longo das vias de tráfego, mas precisamente nas calçadas e canteiros centrais ou de rotatórias (BUCCHERI FILHO; NUCCI, 2006), assim como as chamadas calçadas ecológicas.

A consciência da importância da paisagem, do ambiente e do verde urbano na vida em geral e na saúde física e mental das pessoas é recente. Os estudos realizados desde os anos 1990 (e para isto a ECO-92 teve um papel fundamental) denunciando os males da vida urbana em função de um ambiente desequilibrado, têm ajudado a reverter o processo de degradação em numerosas cidades no Brasil e mundo afora, seja por iniciativa dos gestores, seja por pressão da população afetada ou mesmo das empresas.

Neste artigo, está-se discutindo o verde viário da cidade de Belém (PA), quanto à situação da vegetação existente em nossas ruas, ao tratamento que ela recebe quanto à legislação e às ações para sua implantação, manutenção e expansão, assim como os benefícios que logradouros mais arborizados poderiam trazer à população. Interessa, nesta discussão, mais os aspectos sociológicos e geográficos da questão, com inserções sempre que necessário de especificações técnicas e urbanísticas.

O verde urbano é um componente importante da arborização das cidades, porém, pouco reconhecido do ponto de vista técnico e administrativo (PIVETTA; SILVA FILHO, 2002). No Brasil, a arborização sistemática de ruas é bem mais recente que nos países europeus, com as primeiras experiências sendo realizadas a cerca de 130 anos. Apesar disto, ainda hoje esta prática tem sido minimizada nas dinâmicas de planejamento e expansão urbana, em detrimento do conforto da população e da qualidade do ambiente (DANTAS; SOUZA, 2004). Paradoxalmente, Belém, que hoje pouco dispõe do verde nas ruas, foi uma das primeiras cidades brasileiras a arborizar os logradouros públicos, o que já acontecia de modo pontual na segunda metade do século XVIII.

São muitos os benefícios que o verde viário, sobretudo a vegetação arbórea, pode proporcionar à qualidade de vida nas cidades. Entre outros, verifica-se: bemestar psicológico; melhor efeito estético; sombra para os pedestres e veículos; redução da velocidade dos ventos; amortecimento do som e amenização da poluição sonora; redução do impacto das chuvas sobre o solo, aumento da infiltração e redução do escoamento superficial; controle do microclima, auxiliando na regulação da temperatura, da umidade e das chuvas; e preservação da fauna (PIVETTA; SILVA FILHO, 2002, op cit).

\section{UM BREVÍSSIMO HISTÓRICO: BELÉM VAI SE TRANSFORMANDO NA CIDADE DAS MANGUEIRAS}

Em sua condição de cidade tropical/equatorial, onde as temperaturas são elevadas em todos os meses do ano, Belém deveria ter preservado em sua paisagem uma farta arborização, o que seria um fator importante para a qualidade de vida urbana. Tal raciocínio é válido para todas as cidades amazônicas. Contudo, nas capitais e no interior o que se vê geralmente são ruas e praças praticamente destituídas de vegetação, salvo algumas exceções. Isto reflete a pouca preocupação dos gestores municipais para com o verde urbano, além da pressão que a especulação imobiliária, o adensamento da ocupação e a expansão pouco adequada das cidades exercem sobre a vegetação, afetando-as - em termos ambientais, sociais e urbanísticos (MILANO, 1990).

Ao longo da história, o melhor exemplo é o da capital: basta lembrar que Belém possui (e por quanto tempo mais?) o título de "cidade das mangueiras". As primeiras notícias que se têm do plantio de mangueiras em Belém remontam ao arquiteto e naturalista Antônio Landi, estudioso de árvores amazônicas e daquelas que foram introduzidas na região, dentre as quais a mangueira (Mangifera indica L.), uma espécie nativa do sul da Ásia. Landi menciona em seus relatórios de governo que algumas dessas árvores vinham sendo plantadas desde 1780, e que ele as plantara, mais tarde, em sua casa e mais abundantemente nas ruas da cidade, durante os 12 anos em que governou como Intendente de Belém (cargo correspondente ao de prefeito). 
De fato, em virtude da história de Plácido e da devoção a N.Sa. de Nazaré, a antiga Estrada de Nazaré (hoje avenida, com tráfego intenso), em que se localizava a ermida onde a Santa havia sido encontrada, fôra arborizada com frondosas mangueiras sob as quais as pessoas acompanhavam a romaria (iniciada em 1793) (BELÉM, 1904).

Em 1848, Alfred Wallace (1939, p, 22), naturalista, geógrafo e biólogo, mencionava que "muitas das estradas públicas são orladas com mangueiras alternadas com mangabeiras, ou paineiras"; nas ruas e largos (praças) apareciam laranjeiras, cafeeiros, mamoeiros, bananeiras, amendoeiras e palmeiras, dentre outras árvores nativas ou exóticas. A população tinha preferência pelas espécies frutíferas. Wallace (1939) registrou, também, que em 1852 os governantes estavam intensificando a arborização das ruas. Mas, o grande apaixonado pela arborização urbana foi, sem dúvida, Antônio Lemos. Assim se refere ele às árvores:

Plantar uma árvore é preparar com solicitude e carinho a sombra doce e benéfica para os vindouros; é construir um abrigo para o ninho das aves; é ter piedade da própria terra que escalda, dando-lhe uma tenda verde e sombria que lhe cubra o fecundo seio ao mesmo tempo que a protege da impiedade máscula do sol (LEMOS, 1902)

Quando ocupou o cargo de Intendente, no período que se estende de 1898 a 1911, Antônio Lemos fez do plantio de mangueiras uma verdadeira missão:

Estou hoje convencido da superioridade das mangueiras - árvore clássica de nossos antepassados, cujas qualidades são inúmeras. Com effeito, desenvolve-se com rapidez, cresce a alturas consideráveis e esgalha com regularidade [...] Sua sombra é ampla e perfeita (LEMOS, 1902).

Antônio Lemos não apenas plantou-as, mas substituiu incessantemente outras espécies existentes nas ruas de Belém (como magnólias do Japão e mangabeiras) por mangueiras (LEMOS, 1903). No início do século XX, o intendente Lemos dizia com orgulho: "Belém é uma das cidades brasileiras melhor e mais fartamente arborizadas" (LEMOS, 1902, op cit.), e que "as densas ramarias da arborização formam altas e majestosas abóbadas, impenetráveis ao sol, para abrigo dos transeuntes" (LEMOS, 1903, op cit.).

Com Lemos teve início uma fase de regularização do verde urbano, havendo a plantação extensiva de mangueiras e a proibição do corte e apedrejamento delas e de outras árvores como as andirobeiras, seringueiras e castanheiras. O intendente reorganizou, para este fim, o Horto Municipal (SARGES, 2002) instalado pelo governo colonial em 1797. O Horto estava situado ao final da Estrada das
Mangabeiras, atual avenida Almirante Tamandaré. Aliás, este era, em 1819, o único logradouro devidamente arborizado de Belém, conforme comentado por Spix e Martius (1981, p. 24), que a descreveram como uma avenida de "belas árvores" que "cresceram em dois decênios, dando troncos frondosos". Outro viajante, o padre Daniel Kidder, considerou-a nos anos 1840 como a "mais linda alameda arborizada que tivemos ocasião de visitar no Brasil” (KIDDER, 1980, p. 184). De acordo com diversos relatos, as demais ruas tinham uma vegetação pouco uniforme quanto às árvores plantadas e à distância entre elas.

Situação bem diferente ocorria no início do século XX, pois o cuidado com a arborização de rua era uma característica não apenas da esfera municipal, mas também do governo do estado. Consultando o "Álbum do Pará”, de Paes de Carvalho (PARÁ, s.d., p. 46, 95-96, 103, 106), o governador exibe em seu relatório de governo fotos de árvores plantadas em ruas e praças de Belém, em tamanhos os mais diversos, fato que demonstra uma permanente preocupação com o plantio. À época, os governantes orgulhavam-se do cuidado com a arborização de ruas e praças. O “Álbum do Estado do Pará”, de Augusto Montenegro (PARÁ, 1908, p. 45) menciona que se plantava mangueiras por todas as partes da cidade, mesmo na periferia, a exemplo das vilas de Pinheiro (atual Icoaraci) e Mosqueiro, e dos bairros do Marco, Souza e Pedreira; e diz: "As praças estão convertidas em parques lindíssimos... Das ruas de Belém, 70 já estão lindamente arborizadas".

\section{O REVERSO DA HISTÓRIA: BELÉM VAI DEIXANDO DE SER A CIDADE DAS MANGUEIRAS}

Não há registro do início da decadência, contudo, nos anos 1960 a cidade ainda era fartamente arborizada, embora sua periferia já revelasse uma forte ausência de arborização. $\mathrm{O}$ descuido com a arborização urbana prosseguiu nas décadas seguintes, acentuadamente quando as baixadas de Belém começaram a ser rapidamente ocupadas. Nos anos 1970 e 1980, a expansão urbana tomou novos rumos, alcançando as áreas distantes, localizadas ao longo das rodovias (TRINDADE JÚNIOR, 1998). Segundo dados da Secretaria Municipal de Urbanismo/Horto Florestal, o plantio de árvores nas ruas e praças em Belém foi caindo progressivamente: 27.979 mudas em 1989; 18.950 mudas em 1990; e em 1991, apenas 4.486 (BRASIL, 1995). Grande parte das mudas vinha sendo plantada com porte muito pequeno, de modo que a morte delas era frequente. 
Assim, gradativamente foi se estabelecendo em Belém uma enorme diferença entre a área central, belamente arborizada graças à herança do passado (embora hoje muitas árvores estejam doentes e envelhecidas) e habitada, predominantemente, pelas classes alta e média; e uma área de expansão com conjuntos habitacionais de classe média ou assentamentos ocupados pela população de baixa renda, em bairros largamente desprovidos de verde nas ruas, e com raras praças que sirvam como pontos de lazer, recreação e encontro.

Hoje, compreende-se que o verde urbano em suas diversas modalidades é responsável por inúmeros benefícios materiais e sociais, além daqueles mais especificamente ligados ao ambiente. Daí porque o Banco Interamericano de Desenvolvimento (BID) menciona que:

Os benefícios sociais das áreas verdes urbanas estão relacionados com a saúde pública, a recreação, aos fatores estéticos [da cidade] e ao bem-estar em geral, especialmente dos segmentos sociais mais pobres da população. Os benefícios ambientais incluem o controle da contaminação do ar e do ruído, a modificação do micro-clima e confere um destaque à paisagem, que traz impactos positivos na psique humana e na educação (BID, 1997).

O verde viário tem sido o menos privilegiado nas recentes intervenções urbanísticas realizadas pela prefeitura ou pelo governo do estado. Mesmo nas avenidas reurbanizadas, como a Brigadeiro Protásio, que contorna o HangarCentro de Convenções, Duque de Caxias e Marquês de Herval, a preocupação urbanística privilegiou a melhoria da circulação de veículos e de pessoas como um elemento isolado de outras funções, dentre elas a importância da vegetação para o microclima e o papel que os canteiros poderiam ter para o lazer, recreação e interação da população em geral, em especial os jovens, as crianças e as pessoas idosas.

Nota-se, naquelas avenidas, canteiros de topografia não plana, de modo que é impossível a prática de algum esporte; os largos canteiros teriam possibilitado que, em vez de jardins padronizados e de pouca relação com o ambiente local, fossem introduzidos ali espaços abertos, intercalados de pequenos núcleos de árvores, que servissem de pontos de encontro para as pessoas dos bairros, sob farta sombra.

$\mathrm{E}$, mesmo considerando as melhorias introduzidas pelos governantes do passado, como a concentração das árvores na área central ou "nobre" da cidade, ainda aí, Belém vai gradativamente perdendo sua característica de "cidade das mangueiras". Isto contradiz o disposto no Plano Diretor de Belém (PDU - Lei Ordinária n. ${ }^{\circ}$, de 13 de janeiro de 1993), em seu artigo 143, onde se afirma como um dos objetivos da política de produção e organização do espaço urbano municipal: "VI - resgatar e valorizar a fisionomia e a visualização dos elementos peculiares à cidade de Belém, como o rio, a baía, os igarapés, as mangueiras e a paisagem construída, especialmente os elementos representativos do patrimônio histórico-cultural".

Outras árvores têm tido o mesmo destino, sem que haja maiores protestos por parte da sociedade civil ou do Judiciário em qualquer nível. Quanto ao Executivo, este tem sido em muitos momentos o responsável pela destruição do verde viário. Recentemente, várias árvores desapareceram misteriosamente da calçada do atual Colégio Universo, na Avenida Serzedelo Corrêa, coincidindo com a reforma daquele estabelecimento de ensino, na parte central da cidade, portanto, à vista tanto de transeuntes comuns, como de autoridades. Na Avenida 25 de setembro, o alargamento e retificação do leito carroçável por ação da prefeitura tem sido feito às custas da supressão do canteiro arborizado que lá existe.

A redução da vegetação das ruas tem comprometido ainda mais os baixos índices de verde urbano em Belém, assim como na maior parte das cidades do país. Neste sentido, a Sociedade Brasileira de Arborização Urbana (SBAU), tomando como critério o acesso aberto e fácil, sugere um índice mínimo de áreas verdes de $15 \mathrm{~m}^{2}$ por habitante, incluindo praças, bosques etc. (HARDER; TAVARES, 2006). A Organização Mundial de Saúde (OMS) sugere um índice de $12 \mathrm{~m}^{2}$ por habitante (BUCCHERI FILHO; NUCCI, 2002, op cit).

Conforme alguns autores (HARDER; TAVARES, 2006, op cit.), o conceito de áreas verdes inclui, além de praças e áreas plantadas com vegetação de acesso livre ao público, a sombra das árvores de rua. No entanto, boa parte dos especialistas na matéria considera essas últimas sob uma categoria distinta que seria, justamente, o verde viário ou de "acompanhamento" viário. Seja como for, não é preciso ser nenhum especialista para constatar que Belém está distante dos padrões ideais de arborização, e que apenas o turista apressado, que se limita à área central, regressa com a bela impressão de ter visitado uma cidade verdadeiramente repleta de mangueiras. Tal visão apressada é boa para o conceito da cidade e para o turismo, mas, infelizmente, não corresponde à real paisagem de Belém.

Há exemplos em Belém de trechos de ruas com verde viário que servem como locais de convivência. Enquadram-se nesta situação as avenidas João Paulo II (ex-1 ${ }^{\circ}$ de Dezembro), a ameaçada 25 de Setembro (que vem sendo convertida em via alternativa de tráfego para o centro) e as largas travessas e Avenidas do bairro da Pedreira - Duque de Caxias, Alferes Costa, Marquês de Herval e Pedro 
Miranda. Nestas últimas, houve, na década de 90 e nesta que finda, a deterioração ou retirada de equipamentos de lazer como quadras, pistas de skate e mini-parques para as crianças.

Depredação de mangueiras, supressão de qualquer tipo de árvore, eliminação de espaços de convivência... São estes verdadeiros crimes contra Belém e sua população, porém consentidos pela legislação municipal, que vê as ruas e calçadas como meros elementos de circulação. Assim sendo, quase tudo é permitido em nome do bom funcionamento do trânsito. No artigo 30, item III, do Código de Posturas (Lei n. ${ }^{\circ}$ 7.055, de 30 de dezembro de 1977), lê-se que é proibido "impedir a passagem de pedestres nas calçadas, com construção de tapumes ou depósito de materiais de construção ou demolição, tabuleiros, veículos ou qualquer outro corpo que sirva de obstáculo para o trânsito livre dos mesmos". Fala-se, portanto, de passagem e não de uma adequada permanência, o que poderia conferir um sentido diferente - verdadeiramente público - às ruas de nossa cidade.

\section{O TRISTE CENÁRIO DAS ÁRVORES DE RUA EM BELÉM}

Um criterioso trabalho de Heliana Brasil (BRASIL, 1995, op cit.) exibe dados importantes sobre a arborização de rua: em 1995 as principais espécies na arborização pública eram a castanhola $(23,7 \%)$, as acácias $(21,9 \%)$, as mangueiras $(21,5 \%)$ e os oitizeiros $(18,0 \%)$. Os dados chamam a atenção pela pouca variedade de árvores frutíferas, o que prejudica a pequena fauna de pássaros que poderia ser alimentada por elas. No ano de 2007, depoimentos de técnicos e engenheiros florestais da Secretaria Municipal de Meio Ambiente (SEMMA) informam que o benjaminzeiro (Ficus microcarpa L., espécie conhecida em outros locais como figueira) passou a disputar com essas espécies, em detrimento da mangueira, embora aquele órgão venha fazendo, recentemente, um esforço quanto ao replantio de mangueiras. ${ }^{1}$

Outros dados importantes, e ao mesmo tempo alarmantes, são mostrados no trabalho de Heliana Brasil. Apenas 7\% das árvores de ruas e praças em Belém podiam ser consideradas sob a categoria de boas. ${ }^{2}$ Das árvores existentes na época (1995), 81,2\% apresentavam algum tipo de infestação, 50\% tinham sua

\footnotetext{
O Relatório Anual da SEMMA (2006) registra um total de 421 mudas plantadas naquele ano e 903 plantadas em 2006 (Relatório Anual SEMMA, 2006/Prefeitura Municipal de Belém).

2 "Árvore vigorosa, não apresentando ataque de pragas, doenças ou injúrias mecânicas, apresentando a forma característica da espécie e não requerendo tratos corretivos” (BRASIL, 1995, p. 73).
}

copa deformada (no caso das mangueiras $82,4 \%$ tinham suas copas deformadas pela competição com os fios elétricos, $85,5 \%$ tinham deformidades no tronco, e $55,0 \%$ estavam com suas raízes expostas às agressões pelas atividades urbanas).

A saúde das árvores pode ser avaliada, também, pelo conjunto de microorganismos que elas abrigam, a exemplo dos musgos $^{3}$ - espécies muito sensíveis à poluição. Quanto menos musgo nas árvores, menos saudáveis elas são. Lisboa e Ilkiu-Borges (1995), chegaram a resultados que indicam claramente a redução da microbiodiversidade em áreas com intensa urbanização. Do total de ocorrências, as unidades de conservação estudadas pelos autores abrigavam quase a metade, 47\%; os dois parques urbanos, Emílio Goeldi e Rodrigues Alves, 23\%; as ruas consideradas principais, $15 \%$; as ruas secundárias, $10 \%$; e as praças, apenas $5 \%$ (LISBOA; ILKIU-BORGES, 1995, p. 199-225).

Cada árvore pode ser considerada como um ecossistema em miniatura, agregando micro-organismos e espécies diversas da flora e da fauna. Na Tabela 1 organizado a partir dos dados de Lisboa e Ilkiu-Borges, observa-se que a maioria das principais espécies de microorganismos, que vivem em troncos e ramos de árvores vivas, é encontrada em áreas menos urbanizadas, que concentraram 79,24\% do total de ocorrências.

As áreas de urbanização mais intensa, que incluem praças e ruas, tinham apenas $20,76 \%$ das briófitas inventariadas. Levando-se em consideração que do total de 419 ocorrências relativas às 26 espécies listadas estudadas, a maioria, ou seja, $361(86,16 \%)$ foi de microorganismos que vivem em árvores (as demais vivem em construções, pedras, objetos, detritos, no solo e na água). Conclui-se que as árvores das áreas urbanizadas estão, no geral, menos sadias por estarem situadas em ambientes perturbados, sujeitos a forte poluição sonora e atmosférica. E, destas 26 espécies, apenas 8 foram encontradas nas áreas mais urbanizadas, geralmente aquelas mais resistentes à intervenção humana ou especializadas em ambientes urbanos.

Uma análise realizada por Araújo Júnior e Cruz (2008) no bosque Rodrigues Alves e entorno dele revelou, também, em relação à microflora presente nas árvores, uma degradação e redução à medida que se aproximava das fontes poluidoras. Neste estudo, os autores focaram seu interesse na quantidade e qualidade dos musgos, notando-se a completa ausência deles em várias árvores localizadas no canteiro central e calçadas da Avenida Almirante Barroso, um ambiente fortemente

Na verdade, o musgo é apenas uma das mais conhecidas espécies dos mais de 20.000 tipos de micro-organismos que vivem nas plantas, pedras, areias etc., que recebem o nome científico genérico de briófitas. 
deteriorado do ponto de vista ambiental. Ao contrário, as árvores situadas no centro do bosque, a dezenas de metros das vias de tráfego, mostraram maior diversidade de liquens, em bom estado de pigmentação (tons de verde). A menor quantidade destes organismos e sua descoloração, indicam que o ambiente está muito poluído, o que dificulta os processos de fotossíntese e a saúde da vida vegetal (macro e microflora).

Tabela 1. Principais espécies de microorganismos que vivem em árvores inventariados em Belém (PA) por Lisboa e Ilkiu-Borges (1995), em áreas mais e menos urbanizadas.

\begin{tabular}{r|r|r|r}
\hline \multicolumn{4}{c}{ LOCAL E NÚMERO DE OCORRÊNCIAS } \\
\hline $\begin{array}{c}\text { Total } \\
\text { estudado }\end{array}$ & $\begin{array}{c}\text { Espécies que vivem } \\
\text { em árvores }\end{array}$ & $\begin{array}{c}\text { Áreas mais } \\
\text { urbanizadas }\end{array}$ & $\begin{array}{c}\text { Áreas menos } \\
\text { urbanizadas }\end{array}$ \\
\hline 419 & 361 & 87 & 332 \\
\hline 100 & 86,16 & 20,76 & 79,24 \\
\hline
\end{tabular}

Organizado pelos autores (2009).

Conforme referido anteriormente, é pequeno o número de árvores frutíferas nas ruas de Belém. A escolha dessas árvores é desaconselhada pelos especialistas em arborização urbana, sob a alegação de que tornam-se objeto de depredação, em virtude do hábito de pessoas que procuram apanhar os frutos (PIVETTA; SILVA FILHO, 2002, op cit.). O intendente Antônio Lemos já chamava a atenção para isto ao indagar: "Quando virá o dia em que as mangueiras deixem e ser apedrejadas ao tempo da frutificação e crivadas de pregos e ganchos pelos trabalhadores urbanos, que assim improvisam cabides para suas roupas e sacolas?” (LEMOS, 1907, p. 205), sendo este último, é claro, outro aspecto relacionado ao modo como a população lida com as árvores na cidade.

Alguns inventários sobre arborização urbana confirmam ser o baixo número de árvores frutíferas uma realidade geral para as cidades brasileiras. Em Piracicaba (SP), das 10 espécies de árvores mais frequentes nas ruas, nenhuma produzia frutos apreciados pelo homem (MICHI; COUTO, 1996), o mesmo ocorrendo em Campina Grande (PB) (DANTAS; SOUZA, 2004, op cit.). Belém pode ser considerada uma exceção, em que as mangueiras ocupam o $3^{\circ}$ e os jambeiros o $7^{\circ}$ lugar na lista das dez árvores mais comuns (BRASIL, 1995, op cit.). E, de uma lista de árvores recomendadas para a arborização urbana no Brasil, elaborada por Pivetta e Silva Filho (2002, op cit.), com base na literatura específica sobre o tema, constam 75 espécies, nenhuma delas com frutos que se possa aproveitar pela população. No entanto, cada vez mais a ecologia demonstra os incontáveis benefícios que as árvores frutíferas trazem para a vida urbana, quando possibilitam integrar pequenos animais e pássaros à vida urbana. Parece aí haver uma completa falta de diálogo entre ambientalistas e técnicos responsáveis pela engenharia urbana.

\section{MITOS E ACUSAÇÕES CONTRA A MANGUEIRA}

É muito frequente que técnicos e outros profissionais da área avoquem argumentos em desfavor das mangueiras. Algumas delas são: a mangueira, pelo porte de sua altura e copa é desaconselhável como arborização de rua. ${ }^{4}$ Ora, numa terra equatorial como Belém, quanto maior a copa, mais adequada seria a árvore pelo sombreamento e bem-estar que provoca; o que parece inadequado é o modo como a mesma é tratada, conforme será visto a seguir. Esta alegação tem levado, durante décadas, à substituição da mangueira por outras espécies, como o oitizeiro (Licania tomentosa), de porte menor que ela, com um fruto sensaboroso, mas que não sofre de acusações.

Outro mito é o de que a mangueira não é recomendável porque os pomos (mangas) causam acidentes nos transeuntes e danificam os carros. Na verdade, as classes de renda mais elevada são aquelas que mais reclamam, apontando danos aos seus carros e não em relação às pessoas. Uma simples consulta aos noticiários pode facilmente revelar que os acidentes e mortes por carros (em acidentes de trânsito) são infinitamente maiores do que os raros casos de pessoas atingidas pela queda de mangas. Portanto, não faz qualquer sentido este argumento, quando invocado em desfavor das mangueiras.

A maior parte das pessoas, de outro modo, sente-se agraciada se uma manga cai perto de si, na certeza de ter em mãos um saboroso fruto. Há, também, os que fazem da manga uma fonte temporária de renda nas épocas de safra, que geralmente se prolonga entre os meses de dezembro e março, coincidindo com o período chuvoso. São fatos que revelam as discordâncias sobre o suposto "mal" que as mangueiras representam à cidade.

${ }^{4}$ Porte pequeno: $5 \mathrm{~m}$; porte médio 8 a $15 \mathrm{~m}$; porte alto ou grande 15 a $25 \mathrm{~m}$, porte muito alto: até $30 \mathrm{~m}$. 
A mangueira é tão rica em variedades que estas generalizações se tornam argumentos descabidos. Em todo o mundo, são cultivadas mais de 250 espécies diferentes, dezenas delas no Brasil (ENCICLOPÉDIA BARSA, 2008). O "manguito" ou "manguita", a manga carlotinha e outras espécies, por exemplo, são frutas muito pequenas, não provocando qualquer dano às pessoas ou aos carros. Quanto ao porte elevado da árvore, há espécies de mangueiras muito mais baixas que as centenárias mangueiras de Belém; uma delas é conhecida popularmente como mangueira "anã". A acusação de que suas raízes danificam as calçadas também não faz sentido: o benjaminzeiro - que vem proliferando nas ruas de Belém - tem raízes extremamente agressivas, quebrando calçadas, danificando alicerces, invadindo tubulações etc. Portanto, não há consistência nos argumentos, que podem ser questionados à simples observação dos fatos que estão na rua à vista de todos.

E, finalmente, as mangueiras podem ser plantadas em canteiros centrais de ruas, em praças e em outros espaços mais amplos, mas não é o que se vê. Mesmo árvores de porte menor que as mangueiras, como as acácias, tinham 94,7\% de suas copas deformadas em virtude da rede elétrica. O que se vê, efetivamente, e o que parece ser a causa maior do combate à mangueira é a competição de qualquer árvore de porte alto (como as que precisam as cidades de uma região quente como a Amazônia) com a rede elétrica, já que 80,78\% das árvores da arborização urbana de Belém disputavam (em 1995 quando o estudo foi feito) e estavam embaralhadas em fios elétricos ou telefônicos (BRASIL, 1995, op cit.).

As mangueiras são árvores muito resistentes às intempéries (chuvas, ventos etc.) e vivem por décadas. Estão perfeitamente adaptadas ao ambiente amazônico, e com sua média de $15 \mathrm{~m}$ de altura máxima, geram vasta sobra. A maior parte das mangueiras de Belém foi plantada numa época em que a cidade ainda não estava poluída, em seu espaço aéreo e em sua paisagem, pela trama de postes e fios reclamados pela vida moderna. Com a mudança dos tempos, elas passaram a ser consideradas como inadequadas e sofreram todo tipo de ataque. Elas, e com elas qualquer árvore de porte médio ou grande.

Apesar disto, houve pessoas sensíveis em diversos planos - política, artes, mídia, ensino etc. - que reconheceram a importância destas árvores na paisagem, na história e na cultura urbana, culminando na consideração das mangueiras como elementos peculiares da fisionomia urbana, conforme disposto no Plano Diretor Urbano de Belém. Os "túneis" de mangueiras, em particular, integram o conjunto paisagístico e histórico da área central, e como tal devem ser preservados como dita, implicitamente, o artigo 24 do Código de Posturas (Lei n. ${ }^{\circ}$ 7.055, de 30 de dezembro de 1977):

III - preservar os conjuntos arquitetônicos, áreas e logradouros públicos da cidade que, pelo estilo ou caráter histórico, sejam tombados, bem assim quaisquer outros que julgar conveniente ao embelezamento e estética da cidade ou, ainda, relacionadas com sua tradição histórica ou folclórica.

$\mathrm{Na}$ verdade, qualquer árvore de rua merece cuidados especiais por parte do poder público e, sobretudo, da população, que seria, em face de uma arborização eficiente, a principal beneficiada. Assim, observa-se na Política Municipal de Meio Ambiente (Lei n. ${ }^{\circ} 8.233$, de 31 de janeiro de 2003), artigo $3^{\circ}$, item X, que uma das competências da Secretaria Municipal de Meio Ambiente (SEMMA) é "programar, executar e conservar a arborização dos logradouros públicos e atividades afins". Em relação a esta atribuição do poder público, há muito que se questionar, quando se considera a precária situação atual do verde viário na capital paraense, cujos problemas aqui expostos são uma pequena mostra.

\section{A IMPORTÂNCIA DA ARBORIZAÇÃo URBANA PARA O MICROCLIMA}

As grandes e médias cidades brasileiras atravessaram as últimas décadas pressionadas pela especulação imobiliária, que teve origem e foi impulsionada pelo rápido crescimento populacional dos últimos 40 anos, o que trouxe graves consequências para o verde urbano. Isto ocorreu sob os olhares da maior parte dos gestores municipais, seja por negligência ou conivência com os agentes imobiliários. Belém não fugiu à regra, e foi ainda mais prejudicada pelas condições geográficas peculiares da cidade, onde as vastas áreas inundáveis limitaram a expansão urbana contínua e, aliadas à valorização dos terrenos mais elevados (as terras firmes), forçaram a ocupação das várzeas, mais conhecidas como "baixadas" (TRINDADE JÚNOR, 1998, op cit.).

A despeito das iniciativas dos governos municipal e estadual em ordenar e reurbanizar a cidade nas últimas décadas, destacando-se a macrodrenagem das "baixadas", a regularização de assentamentos informais (as “invasões”) e a reforma de logradouros públicos, muito pouco se fez em relação ao verde urbano. O 
que se vê nessas áreas saneadas, especialmente aquelas beneficiadas pelo projeto macrodrenagem, é uma abundância de concreto, compondo uma arquitetura extremamente pobre e antiestética, que margeia os canais. Este tipo de projeto distoa completamente do que se vê hoje nas cidades mais bem cuidadas, onde os rios vêm sendo recuperados, as margens revitalizadas com árvores e embelezadas por uma arquitetura de concreto mais leve, mais estética e menos agressiva. Essa é uma tendência mundial e não apenas das cidades europeias e americanas, mas de muitas das cidades do Sul e mesmo do Sudeste brasileiro.

Por causa da redução da vegetação, associada à combustão gerada por um tráfego cada vez mais intenso, o microclima de Belém vem sendo modificado, de modo que aumenta a quantidade de energia acumulada no ambiente, a sensação de calor e, por conseguinte, o desconforto térmico (NASCIMENTO, 1995), padecendo a população que transita cotidianamente pelas ruas.

Do ponto de vista urbanístico, a arborização tem várias funções na regulação do microclima: diminui a temperatura ambiente e aumenta a umidade e quantidade de chuvas; reduz a poluição atmosférica e a poluição sonora; retém a poeira; produz sombreamento (AMBIENTEBRASIL..., 2006); promove o sombreamento dos carros estacionados (GREY; DENEKE, 1978); é ainda responsável pela diminuição do calor da cidade, uma vez que a arborização capta mais de $90 \%$ das radiações solares (LARCHER, 1986).

Os dados contidos no estudo de Nascimento (1995, op cit.) permitem construir séries de temperaturas para diversos locais de Belém (Gráfico 1). Naqueles mais arborizados e com menor densidade de construções - áreas do aeroporto, Embrapa e praças da República e Batista Campos - foram registradas, às 15:00 h do dia 28 de maio de 1990, as menores temperaturas (inferiores a $32^{\circ} \mathrm{C}$ ), atestando a importância da vegetação para o controle microclimático. $\mathrm{Na}$ sequência, dois "túneis" de mangueiras - avenidas Presidente Vargas e Magalhães Barata -, situados em áreas fortemente urbanizadas, alcançaram temperaturas entre $32^{\circ} \mathrm{C}$ e $33^{\circ} \mathrm{C}$, o que deve estar ligado à presença do verde viário ali existente - um indicativo do quanto as mangueiras são importantes para a cidade.

As maiores temperaturas (bem acima de $33^{\circ} \mathrm{C}$ ) correspondem aos locais com pouca (ou nenhuma) arborização, grande adensamento de construções e de intenso tráfego - reunindo, assim, três fatores que muito contribuem para o aumento da temperatura ambiente. O estudo enquadrou nesta categoria ruas como as extremidades da rua dos Tamoios, Liberato de Castro e a rodovia Pedro Álvares Cabral, todas situadas na periferia ou semiperiferia urbana.
A rua Siqueira Mendes, apesar de sua fraca arborização, é favorecida pela localização próxima à orla fluvial, o que faz com que a temperatura $\left(32,5^{\circ} \mathrm{C}\right)$ seja menor à tarde que na maioria dos demais locais registrados no Gráfico 1 , mais afastados da baía do Guajará ou do rio Guamá. O mesmo não acontece no Ver-oPeso $\left(33^{\circ} \mathrm{C}\right)$, onde a extensiva cobertura em cimento e asfalto faz as temperaturas se elevarem, a despeito da localização às margens da baía de Guajará. Este fato suscita a necessidade de se fiscalizar as condições em que a orla fluvial vem sendo ocupada.

No que diz respeito à pavimentação do solo, a Lei municipal no. 7.399, de janeiro de 1988, que trata do Parcelamento e Uso do Solo no Município de Belém, estabelece no art. $26, \S 2^{\circ}$, que as vias de circulação deverão dispor, no mínimo de $20 \%$ de sua área permeável arborizada, o que raramente acontece. Aqui, neste caso, falha o poder público quando não exige ou acorda com as construtoras de modo que, pelo menos, os inúmeros edifícios recém-construídos, os supermercados, colégios, shopping-centers, hospitais etc. cumpram a legislação. Isto remete aos índices de espaço construído na cidade, em que se articulam de modo complexo o uso do solo e zoneamento do mesmo com as questões fundiária (propriedade) e ambiental (SOUZA, 2002). Por outro lado, a legislação municipal é incongruente e lacunosa quanto à arborização de rua. Em primeiro lugar, porque menciona que a obrigação de construir as calçadas é do particular (após o poder público ter feito o meio-fio), mas não faz qualquer referência ao plantio de árvores na calçada feita pelo morador. Por outro lado, não impõe qualquer obrigação de limpeza, manutenção, vigilância, cuidado ou outro qualquer ao morador, como se a arborização pública que fica em frente à sua casa ou às proximidades não lhe dissesse respeito como cidadão. A legislação (Código de Posturas e outros dispositivos) do final do século XIX e do início do século XX quanto à questão era muito mais explícita, assim como a fiscalização e as penalidades e multas impostas. Dessa forma, as mangueiras sobreviveram, graças aos cuidados de governantes zelosos e sensíveis como Antônio Lemos (SARGES, 2000) e outros que se seguiram a ele no início do século (CRUZ'1973, p. 434 et seq.). 


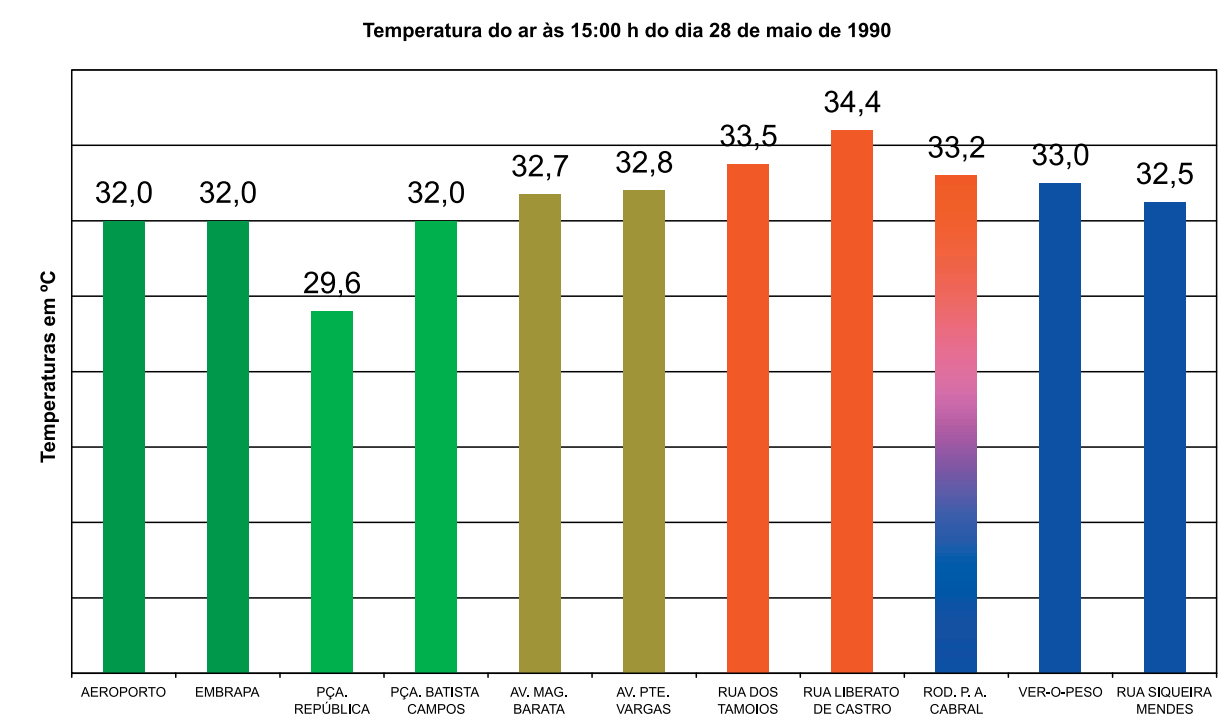

Gráfico 1. Temperatura do ar às $15 \mathrm{~h}$ do dia 28 de maio de 1990, na cidade de Belém (PA). Elaborado pelos autores deste (2009) com base em dados de Nascimento (1995).

Ora, numa cidade tropical/equatorial sem estações bem definidas, com temperaturas sempre elevadas e situada em terreno relativamente plano, é a presença da vegetação, de cursos d'água, o tipo de cobertura do solo e o modo como as edificações estão dispostas umas em relação às outras que vão definir as diferenças de temperatura no interior do espaço urbano (NASCIMENTO, 1995, op cit.). Caso a superfície não estivesse tão desordenadamente ocupada (o que continua a acontecer), estima-se que a diferença de temperatura entre os locais mais e menos quentes fosse de cerca de $2^{\circ} \mathrm{C}$, em virtude de um fenômeno comum na Amazônia, a isotermia - baixa variação espacial e temporal das temperaturas ao longo dos dias, dos meses e dos anos (IBGE, 1990).

$\mathrm{Na}$ Tabela 2, este fenômeno pode ser observado às 09:00 h, quando o ambiente ainda está se aquecendo, e às 21:00 h, momento em que grande parte da energia acumulada no dia já foi devolvida para a atmosfera. No primeiro caso a diferença entre a Embrapa $\left(26^{\circ} \mathrm{C}\right)$, local muito arborizado, e algumas ruas próximas à orla fluvial $\left(28^{\circ} \mathrm{C}\right)$ é de apenas $2^{\circ} \mathrm{C}$. Nas primeiras horas da manhã, é comum que os espaços da orla sejam, em virtude do padrão de circulação dos ventos, os locais mais quentes (NASCIMENTO, id. Ibid.). E, no segundo caso, às 21:00 h, a diferença registrada entre o Aeroporto $\left(25^{\circ} \mathrm{C}\right)$ e o Ver-o-Peso $\left(27,5^{\circ} \mathrm{C}\right)$ foi semelhante, com apenas $\left.2,1^{\circ} \mathrm{C}\right)$. Neste caso, uma superfície inteiramente revestida em cimento como a do Ver-o-Peso, vai acumular energia e se manter mais aquecida, por mais tempo, do que um local com amplas extensões de solo exposto, baixa densidade de construções e de maior umidade (garantida pelos vegetais e solo descoberto) como o Aeroporto.

Tabela 2. Diferença de temperatura $\left({ }^{\circ} \mathrm{C}\right)$ entre as máximas e mínimas registradas no dia 28 de maio de 1990 - com base em Nascimento (1995). Cidade de Belém (PA).

\begin{tabular}{|c|c|c|c|}
\hline HORA & $\begin{array}{c}\text { TEMP. MÁXIMA - } \\
\text { LOCAL }\end{array}$ & $\begin{array}{c}\text { TEMP. MÍNIMA - } \\
\text { LOCAL }\end{array}$ & DIFERENÇA \\
\hline 09:00 & $\begin{array}{l}28,0 \\
\text { Rod. P. A. Cabral, Ver- } \\
\text { o-Peso, Rua Siqueira } \\
\text { Mendes. }\end{array}$ & $\begin{array}{c}26,0 \\
\text { EMBRAPA }\end{array}$ & 2,0 \\
\hline $12: 00$ & $\begin{array}{l}33,0 \\
\text { Rua Liberato de Castro }\end{array}$ & $\begin{array}{c}30,0 \\
\text { Pça. Batista Campos }\end{array}$ & 3,0 \\
\hline 15:00 & $\begin{array}{l}34,4 \\
\text { Rua Liberato de Castro }\end{array}$ & $\begin{array}{c}29,6 \\
\text { Pça. da República }\end{array}$ & 4,8 \\
\hline 18:00 & $\begin{array}{l}30,5 \\
\text { Av. Mag. Barata }\end{array}$ & $\begin{array}{c}26,5 \\
\text { EMBRAPA }\end{array}$ & 4 \\
\hline 21:00 & $\begin{array}{l}27,5 \\
\text { Ver-o-Peso }\end{array}$ & $\begin{array}{c}25,4 \\
\text { Aeroporto }\end{array}$ & 2,1 \\
\hline
\end{tabular}

Elaborado pelos autores (2009).

Mas, às 12:00h, às 15:00h e às 18:00h estas diferenças são mais expressivas, culminado em $4,8^{\circ} \mathrm{C}$, registrados na metade da tarde entre a rua Liberato de Casto $\left(34,4^{\circ} \mathrm{C}\right)$, situada na periferia adensada e de fraca arborização, e a praça da República $\left(29^{\circ} \mathrm{C}\right)$, bastante arborizada. Nos três horários, os locais de menor temperatura são sempre os de mais farta arborização. Às 18:00h, a maior temperatura verificada na Avenida Magalhães Barata pode estar relacionada ao rush que se estabelece nesse horário, quando o aumento da combustão pelo intenso tráfego aquece em demasia o ambiente.

Espera-se, em face destas demonstrações acerca das influências que o espaço construído exerce sobre as temperaturas, ter aqui a afirmação da importância do verde urbano para o microclima. Foi mostrado, com base em estudo de caso de 
Nascimento (1995), que estas características marcam uma diferença de temperatura de até $4,8^{\circ} \mathrm{C}$ entre uma área densamente ocupada e construída e outra com realidade oposta; este valor é muito próximo da média verificada para a chamada "ilha de calor" nas metrópoles, que é de $5^{\circ} \mathrm{C}$. (LOMBARDO, 1985). Esta era a situação em 1990; como estará hoje a cidade, após tantas novas edificações?

Para finalizar, vale ressaltar que as médias de temperatura em Belém são, no geral, superiores ao optimum estabelecido pelo Índice de Conforto Equatorial (I.C.E.), que é de $25,5^{\circ} \mathrm{C}$, com variações entre $23^{\circ}$ e $27^{\circ} \mathrm{C}$ (FROTA; SCHIFFER, 2003). Assim, somente é possível alcançar um melhor I.C.E. por meio de medidas de intervenção, sobretudo nas áreas já alteradas, como o são as cidades e o entorno delas. Portanto, o planejamento urbano deve ter como um de seus vetores o microclima urbano, levando-se em conta a cobertura do solo, os materiais de construção e suas diferentes respostas térmicas, e a localização das ruas e edificações. Deve-se aproveitar, em particular, a potencialidade da vegetação, associada aos ventos e à drenagem, para o conforto térmico.

\section{A INCOMPATIBILIDADE COM A REDE DE DISTRIBUIÇÃO DE ENERGIA ELÉTRICA}

A fiação elétrica aérea, que se apoia em postes, apresenta uma intrincada rede, disposta simultaneamente em várias alturas: os fios de baixa tensão (110 a $220 \mathrm{v})$ aos $6 \mathrm{~m}$; os de alta tensão (13.000 a 22.000v) aos $10 \mathrm{~m}$; e os de distribuição aos $13 \mathrm{~m}$. Já os fios telefônicos estão situados entre 4 e $5 \mathrm{~m}$. Além desses, há ainda os fios de TV a cabo. É preciso notar que os fios telefônicos e de TV são fortemente encapados e grossos, apresentando menos problemas à arborização, pois podem ser facilmente manejados e não provocam curtos-circuitos. Assim, sua convivência com as árvores é mais harmônica, apesar da pouca altura em que ficam dispostos. A contradição é que mesmo estes integram a rotina de podagem urbana, quando são feitos os serviços de poda para proteger outros tipos de fios.

$\mathrm{Na}$ fiação elétrica comum ou convencional, que é a predominante em Belém e na maioria das cidades da região, encontram-se grupos de três fios de alumínio nus (não isolados), paralelos para a alta tensão ou rede primária de distribuição, e mais quatro de baixa tensão ou rede secundária. Devido à incompatibilidade da fiação convencional com qualquer tipo de árvore (o contato entre fios e galhos pode causar curtos-circuitos), a arborização de Belém disputa com ela um espaço para viver. Não que não haja solução para uma convivência pacífica entre rede de distribuição de energia elétrica e arborização das ruas, conforme se tentará demonstrar a seguir.

É preciso considerar que a tecnologia tem avançado continuamente, de modo que há diferentes tipos de cabos (fios) elétricos, possibilitando, assim, uma convivência melhor com as árvores, dando-lhes um pouco mais do cuidado que elas suplicam há décadas. São os chamados "fios ecológicos". Entre esses novos tipos de fios estão o multiplex (fio de alumínio encapado), próprios para redes de distribuição elétrica em áreas arborizadas; e o XLPE TR (fio com condutor e capeamento de alumínio), recomendado para locais em que o contato com árvores é apenas eventual. ${ }^{5}$

Os cabos multiplex e XLPE-TR podem ser utilizados em redes de distribuição aérea compactas, denominadas space, em que todos os fios se encontram juntos, "amarrados" por estruturas especiais. Além de ocupar menos espaço e diminuir o impacto visual da fiação, a rede space ajuda a reduzir o conflito com a arborização. Os cabos multiplex, por consistirem em fios protegidos por uma capa, por si só já contribuem para evitar curtos-circuitos; esta proteção pode ser reforçada por espaçadores entre os fios. Ambos os sistemas permitem diminuir a frequência da poda, o que possibilita que a planta seja menos agredida por cortes. Em Belém, trechos da rede space foram colocados em apenas algumas ruas como a Av. Magalhães Barata, Conselheiro Furtado, parte da Gentil Bittencourt (que, mesmo assim, não foi poupada da poda rasa, entre os trechos da Presidente Pernambuco e da Serzedelo Correa, a ponto de provocar a morte de algumas árvores adultas e de bom porte), dentre outras poucas ruas.

Estudos realizados por Velasco, Lima e Couto (2006) sobre os custos de diversas redes aéreas de distribuição mostram que a disputa entre elas e as árvores nas calçadas pode ser perfeitamente equacionada se as concessionárias abdicarem de uma parte insignificante de seus lucros em favor da coletividade, ao decidirem atuar com maior responsabilidade social e ambiental. Não se está aqui cogitando da rede subterrânea, que seria a mais adequada para as cidades, em termos estéticos (paisagem), arquitetônicos (conjunto das construções e infraestruturas) e até mesmo funcionais (conjunto das diversas atividades), já que esta parece ser uma possibilidade muito remota, pelo menos em países como o Brasil, onde não

Informações disponíveis no site da Elefio Cabos Elétricos. 
existe uma cultura de planejamento urbano consolidada. No Brasil, e Belém não foge à regra; os órgãos não planejam conjuntamente nem se programam para realizar obras conjunta e simultamente. Dessa forma, é comum observar-se que, logo após um órgão quebrar as calçadas ou a rua para colocar uma determinada rede, um outro órgão ou empresa quebra a mesma calçada para colocar uma rede de outro tipo ou realizar um serviço qualquer. E, mais que isto - não recompõe convenientemente o trabalho feito em data anterior pelo outro prestador de serviços. Se houvesse um mínimo de bom senso na aplicação dos recursos públicos, seria possível construir uma tubulação subterrânea por onde circulassem tubos e fios dos diversos órgãos prestadores de serviços e de empresas privadas, como já se faz na Europa há mais de um século e com muito mais economia.

A diferença entre o custo das redes aéreas de distribuição que permitem a plenitude das funções ecológicas das plantas, com os custos da rede convencional, não é grande. Realizado em quatro concessionárias de energia e em cidades distintas, ${ }^{6}$ o estudo citado mostrou que o custo por $\mathrm{km}$ de rede convencional variava entre R \$ 54 mil e R \$67,5 mil (somente a fiação, sem considerar a instalação dos postes, custo que é idêntico em qualquer uma das redes). O custo de implantação da rede compacta (space) foi, em média, de R\$ 62 mil. Já a rede subterrânea, apresenta uma diferença expressiva $(\mathrm{R} \$ 436,5 / \mathrm{km})$, que torna seu uso bastante oneroso, se construído por um único prestador de serviço público; mas, barata se compartilhada por vários usuários.

Mesmo sem cogitar do uso da rede subterrânea, a utilização de redes com "fios ecológicos", seja pelo sistema space ou semi-convencional (cabos encapados), é perfeitamente viável, já que a diferença é pouco relevante. Acresce a isto o fato de que a rede compacta exige menos cuidados e menor custo de manutenção, além de economizar nos custos de podagem, já que estas se tornam menos frequentes.

É plenamente possível substituir a rede convencional pela space, aproveitando grande parte do material da rede já existente. Estudo realizado pela Companhia Paranaense de Energia Elétrica (COPEL) em 2005 (disponível no site da empresa), evidencia que essa transformação é mais simples do que pode parecer, uma vez que os postes da rede anterior podem ser totalmente aproveitados, o mesmo traçado mantido e o trabalho pode ser feito por etapas, e não de uma única vez.

Assim, o custo da rede aérea semiconvencional, ou rede protegida, é bastante semelhante ao da rede convencional, tanto nos custos de instalação como LIGHT/RJ - Rio de Janeiro (RJ). na infraestrutura necessária. A principal diferença entre ambas é que a primeira utiliza cabos isolados do tipo multiplex. Porém, quando se considera os custos de manutenção (especialmente aqueles relativos às podas), o custo total torna-se muito distinto, em favor da fiação com cabos protegidos (Tabela 3).

Tabela 3. Diferenças entre as redes aéreas de distribuição de energia elétrica convencional e protegida. Adaptado de Brito e Castro (2007).

\begin{tabular}{|c|c|c|c|}
\hline & $\begin{array}{c}\text { Rede aérea } \\
\text { convencional } \\
\text { (RAC) }\end{array}$ & $\begin{array}{c}\text { Rede aérea } \\
\text { protegida (RAP) }\end{array}$ & $\begin{array}{c}\text { Diferença de } \\
\text { custos da RAC } \\
\text { para a RAP (US\$) }\end{array}$ \\
\hline Características & $\begin{array}{l}\text { Posteação, cabos } \\
\text { de alumínio nus, } \\
\text { espaçadores, } \\
\text { suscetível a } \\
\text { curtos-circuitos } \\
\text { pelo contato com } \\
\text { árvores. }\end{array}$ & $\begin{array}{l}\text { Posteação, } \\
\text { cabos potegidos } \\
\text { multiplex, } \\
\text { espaçadores, } \\
\text { pouco suscetível } \\
\text { a curtos-circuitos } \\
\text { pelo contato com } \\
\text { árvores. }\end{array}$ & - \\
\hline $\begin{array}{l}\text { Investimento inicial } \\
\text { de instação (US\$) }\end{array}$ & $1.730,00$ & $1.983,00$ & $-253(-12,76 \%)$ \\
\hline $\begin{array}{l}\text { Custo de } \\
\text { manutenção } \\
\text { preventiva - US\$ } \\
\text { poste/ano }\end{array}$ & $1.135,00$ & 180 & $955(+84,14 \%)$ \\
\hline $\begin{array}{l}\text { Custo de } \\
\text { manutenção } \\
\text { corretiva - US\$ } \\
\text { poste/ano }\end{array}$ & 155 & 34 & $121(+78,06)$ \\
\hline
\end{tabular}

Elaborado pelos autores (2009).

Um estudo de Brito e Castro (2007) realizado sobre a rede de distribuição da Companhia Elétrica de Minas Gerais (CEMIG) apontou que o investimento inicial da rede convencional em 2007 era de US $\$ 1.730,00$, e para a rede protegida, de US\$1.983,00, logo, uma diferença pequena (12,76\%). Contudo, verificou-se que os custos anuais de poda para manutenção preventiva na rede convencional frágil ao contato com árvores - eram de US $\$ 1.155,00$ por poste, e de manutenção corretiva, US $\$ 155,00$ por poste. Com desempenho muitas vezes melhor, os custos de manutenção preventiva da rede protegida ficavam em US $\$ 180,00$ por poste, e na corretiva apenas US $\$ 34,00$ por poste. 
Mesmo com essas vantagens econômicas e ambientais, por que as concessionárias de energia ainda optam, na maioria de suas operações em espaços urbanos (e também nos rurais), pela rede aérea convencional? Esta parece ser uma questão com muitas respostas. Primeiro, é possível que as equipes a serviço das concessionárias não estejam preparadas para lidar com tecnologias mais avançadas - até porque, da parte dos dirigentes, investir em qualificação de pessoal ou contratar funcionários com maior qualificação implica em aumento dos custos, pelos menos a curto prazo (mas que certamente, é compensado a médio e longo prazos).

É, sem dúvida, o lucro das concessionárias o que mais conta, ainda que a longo prazo os custos de uma rede não convencional sejam comprovadamente, menores (Tabela 3). Trata-se, portanto, de priorizar a economia da empresa distribuidora de luz, em detrimento do bem-estar da população e da estética da cidade. Sabendo-se que as concessionárias de energia elétrica costumam repassar qualquer reparo no seu sistema para as tarifas de consumo (condição abusiva, porém permitida pela agência reguladora de energia - ANEEL), estas preferem manter os sistemas obsoletos e danosos ao bem-estar comum do que reduzir suas margens de lucro.

\section{A PODA RADICAL (OU CRIMINOSA?) DAS ÁRVORES DE BELÉM E OUTROS ASPECTOS RELACIONADOS À AGRESSÃO DO VERDE VIÁRIO}

A poda é uma prática de remoção de galhos da arborização, com vistas a aumentar a vitalidade das árvores e evitar problemas de segurança. A poda radical ou drástica (cortando-se a copa inteira e deixando-se apenas galhos) consiste numa mutilação da árvore, e somente é permitida quando se trata de ameaça à vida e à segurança das pessoas, segundo o Código Florestal - Lei n. ${ }^{\circ}$ 4.771, de 15 de setembro de 1965 (LANGOWSKI; KLECHOWICZ, 2001). Diferentemente do que muitos podem pensar, a poda drástica não rejuvenesce a árvore; ao contrário, mutila-a definitivamente e, por deixá-la torta, torna-a vulnerável, sujeita à queda (CRESTANA, 1996) e ao ataque de fungos (BRASIL,1995, op cit.). Em princípio, quando não se trata de eliminar ervas daninhas, cupins, fungos, remover partes danificadas, evitar queda de galhos quebrados ou secos e outras razões relevantes, a poda é sempre um ato desaconselhável.
A poda das árvores de rua em Belém é partilhada entre dois órgãos: a Rede Celpa, que poda as árvores "comuns", isto é, exceto as mangueiras, protegidas pela legislação municipal; e a SEMMA-Secretaria Municipal de Meio Ambiente, que efetua a poda das mangueiras e outras espécies, conforme acordo de programação entre ambas. É de se notar, entretanto, que em face da exiguidade de pessoal e equipamentos, a SEMMA vem se restringindo cada vez mais à poda das mangueiras, enquanto a Rede Celpa poda as demais espécies (embora acompanhada por técnicos da SEMMA).

Deste modo, o critério que predomina na hora de decidir pela poda das árvores é o da preservação da rede elétrica, e não da arborização e do bem-estar coletivo. É evidente e esperado, até que uma empresa privada tenha como foco principal o lucro; contudo, no caso em discussão, não se trata de uma empresa como as outras, que vende calçados, roupas ou papéis. Trata-se de uma concessionária de serviço público, cujo sentido principal não é o lucro, embora ele seja um resultado desejável. A mutilação das árvores, em função dos fios e não do bem-estar da população, deixa claro que este elemento não está sendo levado em consideração como deveria - daí porque a poda drástica deveria ser sustada imediatamente em Belém - pelo menos da maneira como vem sendo conduzida.

Uma vez que as árvores das vias públicas pertencem à coletividade - pois elas se localizam e integram logradouros públicos -, é o poder público o principal responsável por elas. Nestes termos, caberia a interveniência do Ministério Público, no sentido de viabilizar um termo de Ajuste de Conduta entre a Rede Celpa e a Prefeitura de Belém, visando adotar um sistema mais moderno de fiação, com a substituição paulatina da frágil e obsoleta rede de distribuição de energia elétrica existente em Belém (com prazos ajustados para tal), bem como para estabelecer parâmetros mais humanizados no trato do verde viário, o que inclui a adoção de novos critérios para a poda de árvores pelos órgãos e empresas envolvidos.

A atual gestão municipal (2007) divulga estar plantando, a cada mês, 16 mil árvores nos oito distritos administrativos de Belém, no âmbito do Plano Diretor de Arborização de Áreas Verdes (PDAVE). No site da Prefeitura Municipal de Belém (PMB), é possível visualizar que o PDAVE tem como princípios básicos:

[realizar] inventário da arborização urbana, criando um banco de dados sobre as árvores urbanas; a regulamentação da conduta para atividades que interferem com a arborização, criando a legislação e a definição das rotinas de manejo; planejamento da expansão da arborização em Belém definindo diretrizes e áreas prioritárias para plantio de novas áreas. 
É, sem dúvida, um esforço louvável, que tomara não fique apenas no discurso ou no papel. É possível observar que árvores vêm sendo plantadas em vários canteiros centrais, rotatórias e áreas verdes, mas as mangueiras estão em minoria entre elas. O PDAVE está combinado ao Programa Plantio e Manutenção, com os seguintes projetos em execução: Complexo de Produção de Mudas; Retirada de Ervas-de-Passarinho (Loretanceae sp.); e Manutenção de Logradouros Públicos. Os números oficiais afirmam que a produção mensal de mudas na Granja Modelo (situada em Ananindeua) é de 30 mil, pretendendo-se chegar a 150 mil mudas. ${ }^{7}$

No que diz respeito à substituição de árvores doentes por novas mudas, verifica-se grande diferença entre as espécies mais comuns nas ruas de Belém. As mangueiras, árvores mais resistentes e longevas, começam a se degradar rapidamente a partir dos 6,0 $\mathrm{m}$ de altura, quando entra em ação o poder público, supostamente para eliminar a competição com a fiação elétrica. Mas, nesta ação, as árvores sempre saem em desvantagem em relação às redes, principalmente porque, além do descuido em geral, são alvo de podas frequentes. Os oitizeiros e as acácias exigem substituição mais rápida; sendo árvores com ciclo de vida mais curto do que as mangueiras - as duas espécies apresentam mais de 60\% de seus indivíduos com situação "ruim", já na faixa de 2,2 a 6,0 m de altura.

As castanholas são as que mais sofrem com as agressões. As espécies mais novas encontram-se, na maioria delas (cerca de 60\%), em situação "ruim" nas faixas de altura de 2,2-6,0 m e 6,0-10,0 m. Apesar disto, as mais antigas conseguem, surpreendentemente, e em comparação com as demais espécies citadas, manteremse em condições "satisfatórias" - 100\% de indivíduos, contra 70\% de mangueiras, $75 \%$ de oitizeiros e $72 \%$ de acácias em situação "ruim”, todas na faixa de altura superior a $10 \mathrm{~m}$, o que indica que as árvores mais altas são as que mais padecem (BRASIL, 1995, op cit.).

As mudanças no trato com a arborização urbana incluem, também, a ação da sociedade civil, que deve ser não apenas conscientizada, mas orientada e, finalmente, penalizada sempre que adotar procedimentos agressivos contra as árvores. As más práticas se referem a atos como a cobertura em cimento do espaço vital para a saúde da planta, que fica ao redor do tronco, asfixiando-a e impedindo-a de absorver os nutrientes; deposição de lixo e material de construção ao pé das árvores; eliminação da vegetação arbórea; afixação de cartazes etc.

7 PREFEITURA MUNICIPAL DE BELÉM. Secretaria municipal de Meio Ambiente. Informações disponíveis no site da PMB.

\section{CONSIDERAÇÕES FINAIS}

Para concluir, algumas perguntas-chave devem ser feitas. A primeira delas é: queremos ou não viver numa cidade sustentável do ponto de vista social e ambiental? Para Liana Matos “o princípio da dignidade da pessoa humana dáse com a concretização dos direitos fundamentais - como o direito à cidade sustentável - irradiando seus efeitos sobre todo o ordenamento jurídico e impondo limites à atividade estatal e às relações privadas travadas no âmbito da sociedade civil e do mercado" (MATTOS, 2002, p. 88).

A segunda pergunta é: se a REDE CELPA, as empresas de TV a cabo e telefonia celular são concessionárias de serviços públicos, não pode o Ministério Público assumir uma posição ativa com relação a elas no que concerne ao verde urbano, disciplinando atitudes, propondo compartilhamentos e outras ações?

Os custos de implantação de uma rede de distribuição compacta ou protegida têm preço equivalente ou pouco superior ao da rede convencional, ${ }^{8}$ sendo perfeitamente viável a substituição da antiga e danosa rede que temos hoje por uma que permita a sobrevivência do verde nas ruas de Belém, evitando mutilações desnecessárias das árvores. O argumento de que a Rede Celpa não tem recursos financeiros disponíveis para arcar com um tratamento mais adequado da arborização urbana de Belém, igualmente não procede. Analisando-se o balanço financeiro do grupo econômico no ano de 2006, o documento declara que a empresa teve um lucro líquido de $\mathrm{R} \$ 88,5$ milhões, que correspondeu a um crescimento de $291,5 \%$ nos lucros em relação ao ano anterior. ${ }^{9}$ Este dado indica que a empresa tem-se capitalizado, contudo, pouco ou nada investiu em melhorias na ultrapassada rede de distribuição, que vem causando danos à cidade de Belém, em especial ao verde viário. É evidente que o objetivo de qualquer empresa numa sociedade capitalista é a obtenção de lucros. Mas, neste caso, não se trata de uma empresa comum e sim de uma concessionária de serviço público essencial, em que o bem-estar da população integra o próprio caráter dos serviços prestados.

A terceira pergunta é: não existe na floresta amazônica - o maior e mais variado banco genético do planeta Terra - um tipo de árvore frutífera que seja

8 Informações das Companhias de Energia Elétrica: COPEL/PR, CPFL/SP, CEMIG/MG e LIGHT/RJ.

9 Segundo o balanço da Rede, a mesma teve um EBITDA (Earnings Before Income Taxes Depreciation and Amortization - ganhos antes dos descontos e de taxas de depreciação e amortização) de $\mathrm{R} \$ 905,4$ milhões. 
ao mesmo tempo bela, frondosa e compatível com a fiação elétrica de Belém? Certamente que sim; e certamente que há centenas de árvores que poderiam compor lindamente a paisagem urbana de Belém, sem abandonar as centenárias mangueiras e outras novas que poderiam ser permanentemente plantadas nos espaços vazios das universidades, nos canteiros centrais de largas avenidas, nos conjuntos habitacionais, tão numerosos em Belém; ou açaizeiros às margens dos nossos feios canais (que há muito deixaram de ser igarapés) etc. O que se constata, de fato, é:

a) que os fios de distribuição de energia elétrica da antiga rede convencional é que são incompatíveis não apenas com as mangueiras, mas com qualquer tipo de árvore e, por isto, precisam ser modificados;

b) que o poder público municipal precisa ter uma ação mais enérgica na fiscalização e atribuição de multas; mais dinâmico na recuperação do verde viário de Belém;

c) e mais criativo ou imaginativo quanto às formas de fazê-lo;

d) que o poder Judiciário não pode ficar omisso em relação a um direito de todo cidadão de viver num ambiente saudável e ecologicamente conservado.

Se quisermos ter e viver numa cidade com visual tipicamente amazônico, tanto a fiação deve ser modernizada, como as árvores selecionadas devem ter a qualidade de embelezar, sombrear, agradar, melhorar a vida das pessoas em contacto com o verde, tanto no centro como nas periferias. Em relação a este último aspecto, é de espantar como a distribuição do verde urbano, considerado um atributo geográfico, indica desigualdades tão marcantes na paisagem; por exemplo, dentre os transectos realizados por Heliana Brasil (1995, op cit.), verificou-se 205 árvores de rua em um bairro "nobre" como Nazaré, e apenas 25 na Condor, um bairro da periferia do sul de Belém. São diferenças explicadas por fatores históricos que fizeram de Nazaré palco de uma intervenção urbanística bem sucedida nos tempos do intendente Antônio Lemos, e da Condor, um espaço de ocupação recente (anos 1960), rápida e sem maiores preocupações quanto ao planejamento e manejo ambiental.

O verde viário deve, assim, ser definitivamente incorporado à prática de planejamento urbano, levando-se em consideração os benefícios que a arborização proporciona à cidade, em termos estéticos, e à população que nela habita, em termos de qualidade de vida - incluída aí a questão do microclima. Foi demonstrado que, hoje, tem-se o oposto do que se espera como ideal: a ação do poder público em relação ao verde viário é insuficiente para prover a farta arborização que uma cidade quente como Belém necessita, e o ambiente urbano se mostra hostil não apenas aos cidadãos, mas também às árvores que existem (e resistem) sob todo tipo de agressão.

Há, em diferentes níveis (em tratados, convenções, na legislação federal, estadual e municipal), princípios e dispositivos que procuram garantir aos cidadãos do mundo urbano o direito de gozar de uma vida espiritual mais plena e mais saudável, através do convívio com a natureza, mesmo na cidade. O convívio com as árvores e a fauna que nelas habitam evita o confinamento estressante e gerador de insensibilidade do ser humano confinado a um mundo cercado pela agressividade do concreto, do ferro, do asfalto, do aço, dos veículos e da poluição de todas as ordens, causadores de tantas neuroses.

A sociedade civil tem a obrigação de intervir nesta questão, por meio de ações relativas à preservação e à expansão do verde urbano de Belém. E aí, campanhas publicitárias educativas devem ser feitas sempre, evidenciando o valor imaterial que o verde confere à vida. De outro modo, a população deve ser penalizada pelos danos e injúrias causadas ao verde, e eles são muitos em Belém.

É interessante ressaltar, ainda, que antes da Constituição Federal de 1988 e da ECO Rio-92, verdadeiros marcos da questão ambiental no Brasil, Belém já dispunha de uma legislação que, se cumprida, teria melhorado de modo considerável a vida de seus habitantes, especialmente aqueles da periferia, já desprovida de tantos serviços urbanos. Porém, pouco foi feito e a precária arborização nas periferias é um reflexo da produção e expansão inadequada da cidade. Em estudo elaborado pelo NAEA (ÁLVARES; DIAS, 2008) os autores mencionam que a gestão das cidades vem sendo cada vez mais pautada por novos paradigmas, dentre os quais se destacam o bem-estar ambiental e a sustentabilidade. Lamentavelmente, não é o que ocorre com Belém.

O que se observa nas ações e intervenções do poder público nas últimas décadas é que elas não respondem aos parâmetros mínimos do desejável, no que tange à estética da paisagem urbana, à melhoria das condições socioambientais e à sustentabilidade no uso do espaço urbano: a má convivência sistemática da cidade com os cursos d água com que a natureza a presenteou, converteu-os ao longo do tempo, de belos igarapés que foram no passado, em insípidos canais de concreto, que posteriormente foram convertidos em valas e, não raros, em esgotos a céu aberto, expostos aos olhos indiferentes dos gestores e dos transeuntes apressados. Uma mulhara de concreto - formada por elevados edifícios que destroem o ralo verde urbano que ainda resistia nos fundos dos quintais - circunda a cidade, 
fazendo um semicírculo que se estende do bairro do Jurunas às margens da Baía do Guajará, aprisionando a cidade numa enorme ilha de calor. Na área central, a depredação das centenárias mangueiras e sua não substituição na mesma medida da destruição, parece indicar que o título de "cidade das mangueiras" também vai fazer parte, num futuro próximo, de um passado nostálgico, que persegue a história de Belém - cidade que inveja seu próprio passado, sem construir adequadamente o seu presente.

\section{REFERÊNCIAS}

ÁLVARES, L. C.; DIAS, P. L. Novos Paradigmas Para a Paisagem Contemporânea: planejamento ambiental e forma urbana na cidade amazônica. Novos Cadernos NAEA, v. 11, n. 2, p.123-138, dez. 2008.

AMBIENTEBRASIL/AMBIENTE URBANO. A Paisagem Urbana. In: CONGRESSO DO CENTRO-OESTE BRASILEIRO SOBRE MUDANÇAS CLIMÁTICAS E EFEITO ESTUFA, 1. 2006, Chapada dos Guimarães. Anais... Chapada dos Guimarães, 2006.

ARAÚJO JÚNIOR, A. C.; CRUZ, M. N. Liquens como bioindicadores de qualidade ambiental no Bosque Rodrigues Alves - Jardim Botânico da Amazônia e entorno. Belém (PA). In: ENCONTRO NACIONAL DE GEÓGRAFOS, 15., 2008, São Paulo. Anais... São Paulo: AGB, 2008.

BID-BANCO INTERAMERICANO DE DESENVOLVIMENTO. Good Practices for Urban Greening. Washington, D. C.: IDB, 1997.

BRASIL, H. Caracterização da arborização urbana: o caso de Belém. Belém: FCAP, 1995. p. 29.

BRITO, M. L. S.; CASTRO, P. M. Viabilidade econômica de redes de distribuição protegidas. Revista da Sociedade Brasileira de Arborização Urbana, v. 2, n. $1,2007$.

BUCCHERI FILHO, A. T.; NUCCI, J. C. Espaços livres, áreas verdes e cobertura vegetal no bairro Alto da XV, Curitiba/PR. Revista do Departamento de Geografia, v. 18, p. 48-59, 2006.
CRESTANA, M. S. M. A importância da poda urbana no paisagismo. In: CURSO EM TRATAMENTO SOBRE PODA EM ESPÉCIES ARBÓREAS FLORESTAIS E DE ARBORIZAÇÃO URBANA, 1. 1996, Piracicaba. Anais... Piracicaba, 1996. out/nov.

CRUZ, E. História do Pará. Belém: Governo do Estado do Pará, 1973. p. 434 e seguintes.

DANTAS, I. C.; SOUZA, C. M. C. Arborização urbana na cidade de Campina Grande - PB: inventários e suas espécies. Revista de Biologia e Ciências da Terra, v. 4, n. 2, jul./dez. 2004.

ENCICLOPÉDIA BARSA. Manga. :São Paulo Barsa Universal, 2008. v. 9.

FROTA, A. B.; SCHIFFER, S. R. Manual de conforto térmico. 7. ed. São Paulo: Nobel, 2003.

GREY, G. W.; DENEKE, F. J. Urban Forestry. New York: John Wiley, 1978.

HARDER, I. C. R.; TAVARES, A. Índices de área verde e cobertura vegetal para as praças do Município de Vinhedo, SP. Revista Árvore, Viçosa, v. 30, n. 2, mar./ abr., 2006.

IBGE-INSTITUTO BRASILEIRO DE GEOGRAFIA E ESTATÍSTICA. Projeto Zoneamento das Potencialidades dos Recursos Naturais da Amazônia Legal. Rio de Janeiro: IBGE, 1990.

KIDDER, D. P. Reminiscências de viagens e permanências nas províncias do norte do Brasil. Belo Horizonte: Itatiaia; São Paulo: Edusp, 1980. p. 184.

LANGOWSKI, E.; KLECHOWICZ, N. A. Manual Prático da Poda. Associação de Proteção ao Meio Ambiente de Cianorte - APROMAC. Curitiba: COPEL, 2001. Disponível em: <www.copel.com>

LARCHER, W. Ecofisiologia Vegetal. São Paulo: USP, 1986.

LEMOS, A. O Município de Belém. Relatório. Belém: Typographia Silva, 1902. LEMOS, A. O Município de Belém. Relatório. Belém: Typographia Silva, 1903.

LISBOA, R. C. L.; ILKIU-BORGES, A. L. Diversidade das briófitas e Belém (PA) e seu potencial como indicadoras de poluição urbana. Boletim do Museu Paraense Emílio Goedi, Série Botânica, Belém, v. 11, n. 2, p. 199-225, dez. 1995. LOMBARDO, M. Ilha de calor nas metrópoles: o exemplo de São Paulo. São Paulo: Hucitec, 1985. 
MATTOS, L. P. Estatuto da cidade comentado. Belo Horizonte: Mandamentos, 2002, p. 88.

MICHI, S. M. P.; COUTO, H. T.Z. Estudo de dois métodos de amostragem de árvores de rua na cidade de Piracicaba - SP. In: CURSO EM TREINAMENTO SOBRE PODA EM ESPÉCIES ÁRVORES FLORESTAIS E DE ARBORIZAÇÃO URBANA, 1. 1996, Piracicaba: IPEF/USP, 1996.

MILANO, M. S. Planejamento da arborização urbana: relação entre árvores e ruas urbanizadas. In: ENCOTRO BRASILEIRO DE ARBORIZAÇÃO URBANA. 1990, Curitiba. Anais... Curitiba, 1990.

NASCIMENTO, C. C. Morfologia e clima urbano em Belém. Belém: NUMA/ UFPA, 1995.

PARÁ. Governo do Estado (1897-1901). J.P. Carvalho. Álbum do Pará. Belém: [s.n.t.], p. 46, 95-96, 103, 106.

PARÁ. Governo do Estado (1901-1909). A. Montenegro. Álbum do Estado do Pará. Paris: Champonet, 1908, p.45.

PIVETTA, K. F.; SILVA FILHO, D. F. Arborização urbana. Jaboticabal: UNESP; FCAV; FUNEP, 2002.

SARGES, M. N. Memórias do velho intendente. Belém: Paka-Tatu, 2002.

SARGES, M. N.Riquezas produzindo a belle époque (1870-1912). Belém: Paka-Tatu, 2000.

SOUZA, M. L. S. Mudar a cidade: uma introdução crítica ao planejamento e à gestão urbanos. Rio de Janeiro: Bertrand Brasil, 2002.

SPIX, J. B. von; MARTIUS, C. F. P. von. Viagem pelo Brasil (1917-1920). Belo Horizonte: Itatiaia; São Paulo: EDUSP, 1981. p. 24.

TRINDADE JÚNIOR, S. C. A cidade dispersa: os novos espaços de assentamento em Belém. 1998. Tese (Doutorado em Geografia) - Faculdade de Filosofia, Letras e Ciências Humanas, Universidade de São Paulo, São Paulo, 1998.

VELASCO, G. N.; LIMA, A. M. L.; COUTO, H. T. Z. Análise comparativa dos custos de diferentes redes de distribuição de energia elétrica no contexto da arborização urbana. São Paulo: USP/ESALQ. Revista Árvore, Viçosa, v. 30, n. 4. jul/ago. 2006.

WALLACE, A. R. Viagens ao Amazonas e rio Negro. São Paulo: Companhia Editora Nacional, 1939. (Coleção. Brasiliana, v.2). 